\title{
PELATIHAN DAN PENDAMPINGAN AKUNTANSI MANAJEMEN UKM BATIK DI BANTUL DAERAH ISTIMEWA YOGYAKARTA
}

\section{TRAINING AND ASSISTANCE IN MANAGEMENT ACCOUNTING UKM BATIK BANTUL YOGYAKARTA REGION}

\author{
${ }^{1)}$ Rahmawati, ${ }^{2}$ Djoko Suharjanto, ${ }^{3)}$ Muthmainah, ${ }^{4}$ Sarah Rum Handayani, \\ ${ }^{5}$ Djamaluddin Subekti, ${ }^{6}$ Setyaningtyas $\mathrm{H},{ }^{7}$ Fitri Susilowati \\ 1,2,3,5,6)Program Studi Akuntansi, Fakultas Ekonomi dan Bisnis Universitas Sebelas Maret \\ ${ }^{4)}$ Program Studi Seni, Fakultas Seni Rupa dan Desain Universitas Sebelas Maret Surakarta, \\ JL. Ir Sutami No.36 A, Pucangsawit, Kec.Jebres, Surakarta, Jawa Tengah 57126 \\ ${ }^{7)}$ Program Studi Manajemen, Fakultas Bisnis Universitas PGRI Yogyakarta \\ Jl. IKIP PGRI I Sonosewu No.117, Sonosewu, Ngestiharjo, Kasihan, Bantul, DIY \\ Email: Rahmaw2005@yahoo.com, fitri.susilowati82@gmail.com
}

\begin{abstract}
ABSTRAK
Program Pengabdian ini dilaksanakan di Desa Pijenan, Wijirejo, Pandak, Bantul Yogyakarta. Mitra dalam kegiatan pengabdian ini adalah UKM Batik Wongso dan Batik Brenda yang memiliki permasalahan sama dengan permasalahan yang dihadapi oleh UKM pada umumnya, yaitu terkait dengan masalah manajemen usaha, administrasi pencatatan/pembukuan, manajemen pemasaran, penyusunan laporan keuangan. Tujuan kegiatan ini adalah untuk meningkatkan kinerja usaha serta kehidupan social ekonomi masyarakat pengrajin sehingga dapat menanggulangi kemiskinan. Metode yang digunakan adalah : (1) Observasi dan Wawancara, (2) Focus Group Discussion (FGD), (3) Analysis kebutuhan pelatihan (4) Pelatihan dan Pendampingan. Observasi dan wawancara dilakukan untuk mendapatkan gambaran umum tentang mitra. FGD dilakukan untuk mengidentifikasi dan membahas secara lebih mendalam terkait dengan permasalahan yang dihadapi oleh mitra. Analisis kebutuhan pelatihan dilakukan untuk menentukan materi yang dibutuhkan oleh mitra. Hasil kegiatann ini adalah :1) Mitra membutuhkan pelatihan tentang kewirauahaan, manajemen usaha, manajemen pemasaran, manajemen operasi dan manajemen keuangan. 2) Pelatihan dan pendampingan dapat meningkatkan kinerja usaha serta kehidupan social ekonomi masyarakat pengrajin.
\end{abstract}

Kata kunci: Batik; Focus Group Discussion; Analisis Kebutuhan

\begin{abstract}
This Community Service Program is implemented in Pijenan Village, Wijirejo, Pandak, Bantul, Yogyakarta. Partners in this service activity are UKM Batik Wongso and Batik Brenda, which have the same problems as the problems faced by UKM in general, which are related to business management issues, administration of records/bookkeeping, marketing management, preparation of financial statements. The purpose of this activity is to improve business performance and the socio-economic life of the artisans so that they can overcome poverty. The methods used are (1) Observation and Interview, (2) Focus Group Discussion (FGD), (3) Analysis of training needs (4) Training and Assistance. Observations and interviews are conducted to get a general picture of partners. The FGD was conducted to identify and discuss in more depth related to the problems faced by partners. Training needs analysis is carried out to determine the material needed by partners. The results of this activity are: 1) Partners need training on entrepreneurship, business management, marketing management, operations management, and financial management.2) Training and assistance can improve business performance and the socio-economic life of the craftsmen community.
\end{abstract}

Keywords: Batik; Focus Group Discussion; Requirements Analysis

Submitted : 23 September 2019 Revision : 11 November 2019 Accepted : 17 Februari 2020 


\section{PENDAHULUAN}

Batik merupakan salah satu produk unggulan di Kabupaten Bantul Daerah Istimewa Yogyakarta. Instruksi Gubernur Daerah Istimewa Yogyakarta nomor 31/KEP/2015 tahun 2015 tentang Produk Unggulan Daerah Istimewa Yogyakarta menjadi salah satu wujud dukungan pemerintah dalam pengembangan batik. Peningkatan produk unggulan yang dilakukan pemerintah melalui promosi, kerjasama, peningkatan peran serta masyarakat dan perlindungan produk unggulan daerah.

UKM Batik Wongso dan UKM Brenda merupakan UKM pengrajin batik yang berada di wilayah Pandak Bantul, Daerah Istimewa Yogyakarta, kedua UKM tersebut memiliki potensi untuk berkembang menjadi industri batik. Masing-masing UKM memiliki keunikan dalam penerapan teknologi maupun desainnya. Produk Batik Wongso dan Batik Brenda memiliki keunikan terkait dengan motif dan desain batiknya, batik Brenda lebih menonjolkan batik lukis dengan motif abstrak kontemporer seangkan untuk batik Wongso menonjolkan kombinasi antara motif kalsik dan modern. Produk yang dijual kedua UKM inijuga bervariasi kain batik, baju, rok, tas, kaos dan lain-lain.

Batik Wongso dan Batik Brenda sebagai UKM yang potensial masih memiliki permasalahan sama dengan permasalahan yang dihadapi oleh UKM pada umumnya, yaitu terkait dengan masalah manajemen usaha, administrasi pencatatan/pembukuan, manajemen pemasaran, penyusunan laporan keuangan.

UKM batik Wongso dan Batik Brenda
masih dikelola dengan manajemen kekeluargaan, yaitu dalam menjalankan kegiatan usahanya belum memisahkan antara kekayaan pribadi dan kekayaan UKM sehingga tidak dapat diketahui secara jelas berapa jumlah kekayaan pribadi dan kekayaan UKM, bagaimana perkembangan modal usaha dan berapa perolehan pendapatan dan juga keuntungan tidak dapat diketahui secara pasti jumlahnya. Selain itu kondisi usaha yang tidak stabil dan banyaknya kebutuhan pribadi yang masih campuraduk dengan kekayaan UKM juga memungkinkan bahwa kekayaan pribadi digunakan untuk memenuhi kebutuhan UKM, contohnya pengadaan alat dan bahan produksi. Demikian sebaliknya kekayaan UKM yang seharusnya peruntukkannya untuk kepentingan UKM digunakan untuk memenuhi kebutuhan pribadi yang mendesak. Kebiasaan dengan manajemen usaha keluarga yang sudah berlangsung bertahun-tahun tentunya akan menimbulkan kebingungan UKM memulai dari mana manajemen usaha yang baik.

Selain pada manajemen usaha yang belum ada pemisahan secara jelas antara kekayaan pribadi dan kekayaan UKM, permasalahan lain yang dihadapi UKM Batik Wongso dan Batik Brenda adalah masalah pencatatan/ pembukuan administrasi. Selama ini pencatatan transaksi tidak dilakukan secara rutin oleh pemilik. Pencatatan hanya sebagian kecil saja ketika pemilik merasa perlu dan transaksi yang diingat oleh pemilik saja. Hal ini tentunya memungkinkan ada transaksi yang tidak tercatat dan akan berdampak pada akuntabilitas dari laporan yang dibuat berdasarkan catatan transaksi. Karena pencatatan hanya sebagian kecil saja membuat pemiliki juga menemukan kesulitan dalam mengidentifikasi dan memulai pencatatan. UKM Batik Wongso dan Batik Brenda juga memiliki keterbatasan dalam mengakses informasi dan keengganan dalam merekrut tenaga administrasi/ tenaga ahli untuk berdiskusi.

Produk UKM batik Wongso maupun Brenda sudah laku dipasaran, tetapi masih terbatas dilingkup Kabupaten Bantul dan sekitarnya saja.Konsumen mengenal produk batik Wongso dan Brenda baru sebatas dari cerita kerabat atau keluarga yang pernah membeli produk batik Wongso dan Brenda. Sebenarnya ditengah kemajuan penjualan secara on-line batik Wongso dan Brenda masih terbatas penjualan secara off-line, itupun belum dikelola secara maksimal.Konsumen atau pelanggan batik Wongso dan Brenda kebanyakan dari penduduk lokal dan instansi sekitar yang biasanya beli untuk seragam kantor.Produk batik Wongso dan Brenda memiliki peluang untuk dipasarkan secara luas karena desain motif yang dibuat oleh batik Wongso dan Brenda beragam tidak hanya klasik saja tetapi juga kontemporer. Produk yang dipasarkan oleh kedua UKM meliputikain batik, baju, rok, dan batik yang dilukis di bahan kaos. Sehingga produk batik Wongso dan 
Brenda tidak hanya digunakan untuk acara resmi saja tetapi juga acara-acara santai bahkan digunakan sehari-hari. Karena keterbatasan promosi yang dilakukan oleh kedua UKM sehingga konsumen yang mengenal produk Wongso dan Brenda hanya wilayah sekitar saja, tentunya jika batik Wongso dan Brenda memiliki akses yang luas dalam pemasaran dapat meningkatkan pendapatan.

Masalah klasik yang juga masih dihadapi oleh kedua UKM tersebut adalah masalah permodalan. Saat ini modal yang digunakan oleh batik Wongso dan Brenda sebatas modal yang dimiliki secara pribadi, sehingga seperti peralatan produksi, show room dan sarana prasarana lainnya masih terbatas. Padahal jika sarana pra sarana dan fasilitas lainnya mendukung dapat meningkatkan kapasitas dan kualitas produksi. Selain itu akses dari UKM Batik Wongso dan Batik Brenda untuk mendapatkan dana masih sebatas dana pribadi karena belum bias mendapatkan pinjaman dengan program untuk usaha hal tersebut dikarenakan batik kedua UKM belum melakukan pembukuan sehingga tidak memiliki laporan keuangan (Neraca, Laba Rugi dan Perubahan Modal) maka upaya pemenuhan kebutuhan dana dengan modal pinjaman seperti KUR masih menjadi kendala.

Tujuan dari kegiatan ini adalah meningkatkan kinerja usaha serta kehidupan social ekonomi masyarakat pengrajin dengan peningkatan potensi masyarakat pengrajin batik sehingga dapat berdampak pada upaya penanggulangan kemiskinan.

\section{METODE}

Karakteristik kedua UKM memiliki kesamaan sehingga dalam pelaksanaan pengandian antara kedua UKM tersebut dilakukan secara bersamaan. Kegiatan pengabdian yang dilakukan pada UKM Batik Wongso dan Brenda yang terletak di Pandak, Bantul, Daerah Istimewa Yogyakarta menggunakan empat metode, yaitu: (1) Observasi dan Wawancara, (2) Focus Group Discussion (FGD), (3) Analysis kebutuhan pelatihan (4) Pelatihan dan Pendampingan.

Pada tahap awal, metode yang digunakan adalah observasi dan wawancara untuk mengetahui gambaran secara umum terkait kondisi dari UKM Batik Wongso dan
Brenda. Berdasarkan hasil observasi dan wawancara pada pemilik UKM Batik Wongso dan Brenda kedua UKM Batik yang potensial untuk dikembangkan menjadi industri batik yang berani disandingkan dan ditandingkan dengan UKM batik sejenisnya. Berdasarkan tahan awal ini ditemukan beberapa permasalahan yang harus segera diselesaikan agar potensi yang dimiliki kedua UKM dapat dikembangkan secara maksimal.

Metode yaang kedua adalah FGD, ini dilakukan dengan tujuan mengidentifikasi kondisi eksisting batik wongso dan brenda secara lebih spesifik. FGD yang dilakukan diharapkan dapat memberikan informasi tingkat kedalaman informasi dari kondisi eksisten secara spesifik dan lengkap. Kedalama informasi terkait kondisi eksisting ini penting karena berhubungan dengan alternatif solusi yang tepat. Focus kondisi eksisting yang dibahas terkait dengan manajemen / pengelolaan usaha yang dilakukan olehkedua UKM.

Metode yang keempat adalah melakukan analisis kebutuhan pelatihan (Training Need Analysis) ( Soenarto, et al., 2019 ; Salas, et al., 2012). Tujuan dari analisis kebutuhan pelatihan ini untuk menyesuaikan isi latihan dengan kebutuhan peserta pelatihan yaitu pengusaha kecil pengrajin batik. Penyusunan analisis kebutuhan pelatihan dilakukan dengan pendekatan konsep enterprising usaha kecil. Enterprising usaha kecil adalah usaha kecil yang dikelola dengan pendekatan perusahaan atau usaha kecil yang menerapkan fungsi-fungsi manajemen didalam pengelolaan usahanya. Fungsi-fungsi manajemen tersebut adalah perencanaan, pengorganisasian, pelaksanaan, dan pengendalian.

Kegiatan usaha kecil pada dasarnya meliputi kegiatan-kegiatan yang menyangkut produksi/teknologi, pemasaran, pengelolaan keuangan/permodalan serta manajemen usaha. Oleh karena itu materi pelatihan berkaitan dengan aspek produksi, pemasaran, keuangan, dan manajemen usaha pengrajin.

Metode keempat adalah pelatihan dan pendampingan dengan materi pelatihan dan pendampingan sesuai hasil analisis kebutuhan 


\section{HASIL DAN PEMBAHASAN}

Analisis kebutuhan pelatihan dilakukan meliputi lima aspek: Aspek kewirauahaan, manajemen dan organisasi, aspek pemasaran, aspek produksi, aspek keuangan.

\section{Asepek Kewirausahaan}

Skor aspek kewirausahaan diilustrasikan dalam table berikut:

Tabel 1. Pengukuran Aspek Kewirausahaan

\begin{tabular}{|l|l|l|l|}
\hline No & Uraian & Ya (1) & $\begin{array}{l}\text { Tidak } \\
(0)\end{array}$ \\
\hline 1 & PercayaDiri & 25 & 0 \\
\hline 2 & MotivasiDiri & 25 & 0 \\
\hline 3 & MenyukaiTantangan & 24 & 1 \\
\hline 4 & Kepemilikan & 4 & 21 \\
\hline 5 & MemperluasPengetahuan & 17 & 8 \\
\hline 6 & Komunikasi & 24 & 1 \\
\hline 7 & Pendengar yang Baik & 25 & 0 \\
\hline RumlahSkor & Berprestasi & 24 & 1 \\
\hline Rata- rata skor & Citra Diri yang Positif & 24 & 1 \\
\hline
\end{tabular}

Berdasarkan tabel tersebut, skor total yang diperoleh dari aspek kewirausahaan adalah 212 dengan rata-rata skor 0,848 , berarti untuk dapat mencapai ideal, derajad jiwa kewirausahaan pengusaha kecil saat ini dalam posisi $84,8 \%$. Untuk mencapai posisi ideal masih diperlukan upaya untuk meningkatkannya, $100 \%$ dari responden menyatakan setuju untuk berpartisipasi dalam berbagai pelatihan. Hal ini menujukkan bahwa pengrajin batik membutuhkan materi pelatihan tentang kewirausahaan.

\section{Manajemen dan Organisasi}

Secara umum profil usaha pengrajin adalah berbentuk usaha perorangan (92\%), berskala usaha kecil (64\%), dengan jenis usaha adalah industry kerajinan perdagangan (92\%), yang dapat dikatakan sebagai industry rumahtangga (home industry) karena rata-rata memiliki tenaga kerja $<5$ orang.
Terbentuknya usaha adalah dari hasil usaha sendiri (48\%), warisan (28\%) dan lainlain $(24 \%)$ dengan lama usaha sebagian besar di bawah 2 tahun (60\%). Sebagian besar pengrajin menjadikan usaha ini sebagai pekerjaan pokok (80\%) dengan tujuan pendirian usaha adalah untuk mencari keuntungan dan pertumbuhan serta menyediakan lapangan pekerjaan.

Berdasarkan analisis data sebanyak $64 \%$ responden tidak memiliki perijinan usaha, $44 \%$ responden tidak melakukan pembagian tugas dan mendelegasikan wewenang, 52\% respondeen tidak memiliki uraian tugas secara jelas, $68 \%$ responden tidak memiliki peraturan gaji dan kepegawaian, $96 \%$ responden membuat perencanaan usaha, $40 \%$ responden tidak melakukan pengarahan dalam pelaksanaan kegiatan, 20\% responden tidak melaksanakan koordinasi dan komunikasi dalam pelaksanaan kegiatan, 30\% responden tidak melakukan pengawasan terhadap jalannya kegiatan. Berdasarkan analisis kebutuhan tersebut materi yang dibutuhkan oleh pengrajin batik dalam bidang manajemen dan organisasi adalah keterampilan mengelola usaha, organisasi usaha, prospek usaha kecil, bentuk usaha dan perijinan, kerjasama dan kemitraan serta lobbying dan negosiasai.

\section{Aspek Pemasaran}

Gambaran umum mengenai kegiatan pemasaran batik yang dilakukan oleh pengrajin adalah : distribusi produk dilakukan oleh pemilik usaha sendiri (64\%) dengan wilayah pemasaran lokal $(84 \%)$.

Dengan kondisi pembayaran penjualan secara kredit (4\%), kontan (96\%), dalam tiga tahun terakhir omzet penjualan cenderung stabil $(64 \%)$ seiring dengan tingkat permintaan yang stabil pula (68\%). Hasil tersebut sudah baik mengingat adanya persaingan dalam usaha ini sebesar (56\%). Peramalan permintaan ada sebesar $96 \%$ serta prospek masa depan bagus $100 \%$ setuju.

Kondisi obyektif kegiatan pemasaran usaha responden diidentifikasi dari jawaban 11 butir pertanyaan kepada responden yang meliputi aspek antara lain : perencanaan pemasaran, strategi pemasaran, dan keterampilan menjual. Derajat pengelolaan usaha diketahui dengan memberikan skor 0 untuk jawaban "Tidak Ada", serta skor 1,2 dan 
3 untuk jawaban "Ada" dalam kondisi "kurang", "cukup" dan "baik".

Berdasarkan anlisis kebutuhan sebanyak $96 \%$ membuat perencanaan namun masih dalam kondisi kurang mampu, $100 \%$ membuat pencatatan penjualan, $100 \%$ responden sudah melakukan perhitungan harga jual produk, $100 \%$ melakukan upaya memposisikan produk di pasaran dengan variable harga, $96 \%$ responden membuat rencana pemasaran masih dalam bentuk masih sangat sederhana, $100 \%$ menggunakan saluran distribusi dan promosi, $76 \%$ responden sudah membuat ramalan permintaan, $36 \%$ responden tidak mengamati situasi persaingan visual, $88 \%$ responden menentukan target pasar bagi produknya, $100 \%$ memiliki cukup ketrampilan menjual produk. Berdasarkan analisis kebutuhan potensi pelatihan dalam bidang pemasaran terutama terfokus pada teknik menjual, strategi pemasaran, peluang pasar, analisis pesaing, analisis pasar dan informasi pemasaran.

\section{Aspek Produksi}

Sistem produksi usaha kecil batik adalah dengan system sesuai pesanan dan proses ( $80 \%$ adalah system produksi harian). Sebagian besar pengrajin (72\%) mengalami kemudahan dalam pengadaan bahan baku dan dengan kualitas yang bagus (92\%).

Kondisi riil usaha kecil dilihat dari aspek pengelolaan produksi dapat diidentifikasi dari jawaban 7 butir pertanyaan yang diberikan oleh responden. Derajad pengelolaan kegiatan produksi dapat diketahui dengan memberikan skor 0 untuk jawaban "Tidak Ada", dan memberikanskor 1, 2 dan 3 bagijawaban "Ada" dengankondisi "kurang", "cukup" dan "baik".

Berdasarkan analisis kebutuhan diperoleh data bahwa $100 \%$ responden merencanakan kualitas produk secara sederhana, $4 \%$ responden yang tidak melakukan perencanaan dalam pengadaan peralatan produksi yang digunakan, $88 \%$ responden telah melakukan pengawasan dalam penggunaan peralatan, $92 \%$ responden telah melaksanakan pengawasan, $100 \%$ responden sudah menyelenggarakan kegiatan berkaitan dengan upaya keselamatan kerja dalam produksi.
Sistem produksi usaha kecil adalah berdasarkan pesanan dan proses, sementara sebagian besar pengrajin tidak mengalami kesulitan pengadaan bahan baku yang berkualitas. Walaupun situasi persaingan pasar batik stabil namun ada kesulitan dalam menjual sendiri ke pasar eksport, responden memiliki motivasi untuk memiliki keterampilan teknis tentang pengembangan batik menggunakan pewarna alam.

\section{Aspek Keuangan}

Gambaran umum mengenai aspek keuangan usaha kecil adalah permodalan sebagian besar bersumber dari Bank/Koperasi (40\%), dana operasional cukup tersedia (56\%), mayoritas pengrajin memiliki rekening di bank (92\%), pengelolaan keuangan ditangani pemilik (92\%), kesulitan mengakses kredit perbankan (44\%), modal kerja usaha berbentuk kas (64 \%) dengan kondisi lancar (72\%) sedangkan aktiva lancer berupa persediaan barang dagangan jumlahnya cukup (60\%). Kinerja usaha dilihat dari keuntungan selama tiga tahun terakhir menunjukkan kecenderungan stabil (64\%).

Derajat pengelolaan keuangan usaha kecil diperoleh dari jawaban 8 butir pertanyaan yang diberikan oleh responden yang diberinilai 0 untuk jawaban "Tidak Ada", serta skor 1,2 dan 3 untuk jawaban "Ada" dalam kondisi "kurang", "cukup" dan "baik".

Berdasarkan analisis kebutuhan diperoleh $52 \%$ responden tidak menyimpan bukti transaksi, 68\% responden melakukan pencatatan transaksi keuangan, aliran kas dan perencanaan kas, $12 \%$ responden tidak mempunyai perencanaan keuntungan usaha, 76\% responden melakukan pengawasan atas terjadinya penyimpanan terhadap anggaran kas, $84 \%$ responden melakukan pengendalian terhadap keuntungn, $88 \%$ responden melakukan pemisahan antara kekayaan pribadi dan usaha. Perencanaan dan pengendalian keuangan serta pembukuan praktis untuk usaha kecil berpotensi menjadi kebutuhan pelatihan demikian pula wawasan tentang pemisahan kekayaan pribadi dan usaha.

Berdasarkan analisis kebutuhan pelatihan, maka dapat disimpulkan materi pelatihan dan pendampingan yang dibutuhkan oleh kedua mitra tersebut, yaitu: 
Kewirausahaan, Manajemen organisasi, manajemen pemasaran manajemen produksi dan manajemen keuangan.

Kegiatan untuk kedua mitra yang pertama adalah penyuluhan untuk memberikan pemahaman terkait dengan materi pelatihan. Setelah pemberian penyuluhan selanjutnya diadakan pendampingan dalam mempraktekkan materi yang sudah didapat dalam penyuluhan tersebut.

Pelatihan dan pendampingan dalam bidang kewirausahaan dengan materi merencanakan usaha, mengelola waktu secara efektif, berpikir kreatif dan inovatif, mengembangkan etos kerja, wirausaha, dan membentuk kepribadian wirausaha. Sebelum mengikuti pelatihan dan pendampingan pengrajin batik dalam menjalankan usahanya mengalir secara alamiah tanpa membuat perencanaan yang jelas, sehingga dalam menjalankan usahanya sekedar jalan saja kurang berinovasi untuk mengembangkan usahanya. Setelah mengikuti pelatihan pengrajin memiliki semangat untuk maju dan optimis dalam menjalankan usahanya, berani membuat perencanaan usaha kedepan, kreatif dan inovatif.

Pelatihan dan pendampingan manajemen organisasi, yang dibutuhkan oleh mitra adalah dalam bidang manajemen organisasi terutama terkait dengan keterampilan-ketrampilan mengelola usaha, organisasi usaha, prospek usaha kecil, bentuk usaha dan perijinan, kerjasama dan kemitraan, serta lobbying dan negosiasi. Setelah mengikuti pelatihan dan pendampingan keterampilan tersebut meningkat dibandingkan dengan sebelum mengikuti pelatihan.

Secara umum profil usaha adalah usaha berskala kecil termasuk kategori industry kecil rumah tangga dengan jenis usaha kerajinan batik. Usaha sebagian besar adalah pekerjaan pokok dan tujuan pendirian usaha mayoritas adalah mencari keuntungan.

Pelatihan dan pendampingan dalam Manajemen Pemasaran difokuskan pada teknik menjual, strategi pemasaran, peluang pasar, analisis pesaing, analisis pasar, dan informasi pemasaran. Setelah mengikuti pelatihan mitra dapat mengetahui tentang strategi pemasaran, peluang pasar. Mitra diberi pendampingan dalam pilihan strategi pemasaran melalui beberapa media supaya masyarakat mengenal produk batik.

Pelatihan manajemen produksi, selama ini sistem produksi usaha kecil berdasarkan pesanan dan proses, namun ada kesulitan dalam menjual sendiri ke pasar ekspor, responden memiliki motivasi untuk memiliki keterampilan teknis tentang pengembangan batik dan menggunakan pewarna alam. Sebelum pelatihan dan pendampingan mitra hanya memproduksi batik warna kimia/sintesis, tetapi setelah mengikuti pelatihan dan pendampingan mitra bias menerapkan penggunaan warna alam pada produk batiknya.

Pelatihan dan pendampingan dalam manajemen keuangan, perencanaan dan pengendalian keuangan serta pembukuan praktis untuk usaha kecil berpotensi menjadi kebutuhan pelatihan. Demikian pula wawasan tentang pemisahan kekayaan pribadi dan usaha. Sebelum mengikuti latihan pencatatan tidak rutin dilakukan sehingga ada transasisi yang terkewat tidak dihitung dalam penyusunan laporan keuangan UKM. Setelah mengikuti kegiatan pelatihan dan pendampingan peserta mampu untuk menyusun laporan keuangan sederhana.

\section{SIMPULAN}

Kegiatan pelatihan dan pendampingan dapat meningkatkan kemampuan mitra dalam melakukan pengelolaan terhadap usahanya, terutama dalam bidang kewirausahaan, manajemen dan organisasi, manajemen pemasaran, manajemen keuangan, manajemen operasi akuntansi dapat meningkatkan kemampuan mitra terutama dalam manajemen usaha, manajemen pemasaran, manajemen operasi.

\section{DAFTAR PUSTAKA}

Keputusan Gubernur Derah Istimewa Yogyakarta Nomor 31/KEP/2015 tentang Produk Unggulan Daerah Istimewa Yogyakarta.

Salas, E., Tannenbaum, S.I., Kraiger, K., Jentsch, K.S., (2012), The Science of Training and Development in Organizations : What Matters in Practice, Psychological 
Rahmawati, Djoko Suharjanto, Muthmainah, Sarah Rum Handayani,

Djamaluddin Subekti, Setyaningtyas H, Fitri Susilowati

Pelatihan dan Pendampingan Akuntansi Manajemen UKM Batik di Bantul Daerah Istimewa Yogyakarta

Science in the Public Interest, 13 (2), 74101.

Soenarto, Rahmawati, Suprapti, A.R., Handayani, R., Sudira, P., (2019), Green Entrepreneurship Development Strategy
Based on Local Characteristic To Support Eco-Tourism Continuous, Jurnal Manajemen, XXIII, (02 ), 257273 